\title{
ANALYSIS OF STUDENT'S BOOK ON FOURTH GRADE BASED ON CURRICULUM 2013 THEMES "MY HEROES" SUBTEMA "THE STRUGGLE OF THE HEROES"
}

\author{
Bernadine Ajeng Indriasari \\ Universitas Katolik Musi Charitas \\ indriasari@ukmc.ac.id
}

\begin{abstract}
The purpose of this research is to know stundent's book of four grade student based on Curricullum 2013 on theme "Pahlawanku" subtheme "Perjuangan Para Pahlawan" on lesson 3with kompetensi dasar, purpose, indicator, learning activity, materials, tool and learning resources. Research method is descriptive method by analyze document is student book of four grade student based on Curricullum 2013 on theme "Pahlawanku" and teacher book of four grade student based on Curricullum 2013. The analize revolves on the rule of Menteri Pendidikan dan Kebudayaan Nasional, an article discussing about the implementation of Curricullum 2013 and article from Badan Nasional Standar Pendidikan (BSNP) website. The result of this research are found that some kompetensi dasar do not appear in indicators and materials that are less in line with the mapping of kompetensi dasar. From the analysis it is conclude that the student's book of four grade student based on Curricullum 2013 on theme "Pahlawanku" subtheme "Perjuangan Para Pahlawan"needs much improved with the discrepancies inlesson 3.
\end{abstract}

Keywords: Analyze, Student book, Curricullum 2013

Learning resources can be interpreted as everything that can be utilized to help achieve the goal of learning. According to Wasita quoted Prastowo (2014: 126) learning resources are divided into two kinds, its: (1) learning resources by utilization and (2) learning resources by design. Learning resources are utilized is everything that is around us that can be utilized for learning purposes. For example: newspapers, television broadcasts, markets, museums, zoos, mosques and religious leaders. While the source of learning is designed is a learning resource that is intentionally planned and made to achieve certain learning goals. Examples: package books, worksheets, modules, manuals, transparencies, films, encyclo-pedias, brochures, strip films, slides, and vidio.

Textbooks or commonly known as a book are the most commonly used learning resources. Textbooks are learning resources designed deliberately to achieve specific learning goals. Achievement of learning objectives carried out through learning activities every day. In the learning activities delivered learning materials or often referred to as teaching materials. This collection of materials is usually the content of the textbook.

The teaching materials themselves have certain criteria in the selection. Quality criteria of teaching materials include feasibility (validity), practicality, and effectiveness (Furidaniyah and Mersigit, 2012). Eligibility criteria refers to the validity of a material to be displayed. The material must be completely valid and validated. Practical criteria are easily understood material. Effective criteria means that material must be able to give a deep impression when taught.

Since July 15, 2015, a new curriculum has been introduced as the Curriculum 2013. The implementation of Curriculum 2013 in elementary school is conducted in class I, class II, class IV and class V (BNSP: 2014). In connection with this, the Ministry of National 
Education and Culture in cooperation with the Center of Curriculum and Books (Puskurbuk) has published a book based on Curriculum 2013 based on teacher books and student books. The 2013 Curriculum-based package book is expected to help students achieve learning purpose.

But after its use for two years, textbooks that have been published by Puskurbuk not meet the demands in Curriculum 2013. The statement by Harta is disclosed in an article on 5 October 2013 on the official website Kompasiana. "This book (red: student book) in meeting the curriculum of the 2013 Curriculum that the book should be work based (seen from the teacher's book), because the student's book contains the theory." "There are a lot of misconceptions and obscure concepts .....". In another article found complaints related to Basic Competence (KD) and indicators. "There is a KD in the syllabus and the book Curriculum 2013 is not in accordance with the Ministerial Regulation ..... there are KD that is not contained in the syllabus or book Curriculum 2013 ... KD charge per subprocessor is not proportional .. weak in understanding KD and formulating indicators .. . "This statement was delivered by Prastica on October 22, 2014 on the official website Kompasiana. Minister of Education and Culture Anies Baswedan in an article on the official site of Sindo newspaper revealed that "..... mistakes are so severe, such as not synchronizing KD material with what is in the hands of students." Curriculum observers, Retno Listysarti also revealed the similar in the same article ".... between the syllabus document, KD and the book is out of sync."

The purpose of this research is to know the appropriateness of fourth grade student's book based on curriculum 2013 on theme "My Heroes" with KD, indicators, activities, materials, tools and learning resources. The book of the fourth graders based on the 2013 curriculum on the theme "Heroes" is divided into 3 sub themes with 6 lessons in each subtemanya. So this research is limited to the book of fourth grade students based on Curriculum 2013 on theme "The Heroes" subtema 1 "Struggle of Heroes" on lesson 3. This is done to improve research accuracy and maximize research result.

\section{METHOD}

This research is a descriptive method by analyzing the contents of documents related to the research problem, namely: the fourth grade student's book theme "My Heroes" based on Curriculum 2013 and the fourth grade teacher's book theme "My Heroes" based on Curriculum 2013. Analysis refers to the Regulation of the Minister of Education and Culture National No. 65 Year 2013 on Standard Process of Primary and Secondary Education, attachment of Regulation of Minister of National Education and Culture No. 67 of 2013 on the Basic Framework and Curriculum Structure of Elementary School / Madrasah Ibtidaiyah, Regulation of the Minister of National Education and National Culture No. 11 of 2005 on Textbook Lessons, Law No. 20 of 2003 on National Education System, articles related to the implementation of Curriculum 2013 and official articles from the BSNP website.

The variables in this study are KD incompatibility, indicators, objectives, activities, materials, tools and learning resources in the fourth grade students book based on Curriculum 2013 on the theme of "My Heroes". Data is collected through the following steps.

The first thing researchers do is to create a suitability analysis format along with a description of conformity. Furthermore, the researcher collects research documents in the form of: fourth grade student's book theme "My Heroes", book teacher grade IV theme "My Heroes", Regulation of Minister of Education and National Culture No. 65 Year 2013 on 
Standard Process of Primary and Secondary Education, Regulation of Minister of Education and National Culture No. 67 of 2013 on Basic Framework and Structure of Elementary School Curriculum / Madrasah Ibtidaiyah, Regulation of the Minister of National Education and Culture No. 11 of 2005 on Textbook Lessons, Law no. 20 of 2003 on National Education System, articles related to the implementation of Curriculum 2013, and articles from the official website of BSNP. After the required documents are collected the researcher begins to analyze the suitability and incompatibility of each $\mathrm{KD}$, indicators, objectives, activities, materials, tools and learning resources on each lesson in a fourth grade student book based on the Curriculum 2013 "Heroes" theme, referring to the official documents collected earlier. After the analysis is done, compliance and non-conformity are sorted. The incompatibility of each learning is collected and tabulated in three tables according to each subtheme of the lesson.

Table 3.1 Assessment grid

\begin{tabular}{|c|c|c|}
\hline $\begin{array}{l}\text { Primary } \\
\text { Domain }\end{array}$ & Attention & Description \\
\hline \multirow[b]{2}{*}{$\begin{array}{l}\text { Basic } \\
\text { Competency }\end{array}$} & 1. KD used in learning. & $\begin{array}{l}\text { 1. KD is the true KD of the subject. } \\
\text { 2. Numbering KD as stated in Curriculum } 2013 .\end{array}$ \\
\hline & 2. Compatibility of KD mapping. & $\begin{array}{l}\text { 1. Hierarchical based on the concept of science or the } \\
\text { degree of difficulty of matter. } \\
\text { 2. KD related based on teaching materials, themes, both } \\
\text { in one subject and between lessons. }\end{array}$ \\
\hline \multirow[t]{3}{*}{ Indicators } & 1. Indicators of each lesson. & $\begin{array}{l}\text { 1. Meet the demands of KD. } \\
\text { 2. Hierarchy based on the level of competence to be } \\
\text { achieved. Depart from Bloom's C1-C6 Taxonomy. } \\
\text { 3. Includes measurable competencies. } \\
\text { 4. Using operational verbs. }\end{array}$ \\
\hline & 2. The order of indicator usage of each KD. & $\begin{array}{l}\text { Hierarchical based on the level of competence to be } \\
\text { achieved. Depart from Bloom's C1-C6 Taxonomy. }\end{array}$ \\
\hline & 3. Compliance indicators with KD. & Indicators include competencies in KD. \\
\hline $\begin{array}{l}\text { Learning } \\
\text { Objectives }\end{array}$ & $\begin{array}{l}\text { Conformity of learning objectives with } \\
\text { predefined indicators. }\end{array}$ & $\begin{array}{l}\text { 1. Objectives include components in the indicator. } \\
\text { 2. Use a phrase that describes the indicators } \\
\text { specifically. }\end{array}$ \\
\hline $\begin{array}{l}\text { Learning } \\
\text { Activities }\end{array}$ & $\begin{array}{l}\text { The suitability of learning activities with goals } \\
\text { that hedak achieved. }\end{array}$ & $\begin{array}{l}\text { 1. Learning activities accommodate all learning } \\
\text { objectives. } \\
\text { 2. The flow of activity is clear. } \\
\text { 3. In accordance with the scientific learning step. }\end{array}$ \\
\hline \multirow[t]{2}{*}{ Material } & $\begin{array}{l}\text { 1. Material compatibility with learning } \\
\text { objectives. }\end{array}$ & $\begin{array}{l}\text { 1. Materials meet the demands of learning objectives, } \\
\text { not widened and not narrowed. } \\
\text { 2. The order of presentation of the material in } \\
\text { accordance with the learning activities. }\end{array}$ \\
\hline & 2. Material depth of each meeting & $\begin{array}{l}\text { 1. The portion of the presentation of the material } \\
\text { according to the degree of difficulty of the material. } \\
\text { 2. Presentation of materials in accordance with the } \\
\text { needs of learning activities, does not depend on the } \\
\text { availability of materials from other sources. }\end{array}$ \\
\hline \multirow{3}{*}{$\begin{array}{l}\text { Tools and } \\
\text { Learning } \\
\text { Resources }\end{array}$} & $\begin{array}{l}\text { 1. The types of learning tools and resources } \\
\text { that are used to support learning }\end{array}$ & $\begin{array}{l}\text { The presence or absence of supporting tools and } \\
\text { resources. }\end{array}$ \\
\hline & $\begin{array}{l}\text { 2. Conformity of learning tools and resources } \\
\text { with learning materials. }\end{array}$ & Tools and resources support the delivery of material. \\
\hline & $\begin{array}{l}\text { 3. The suitability of learning tools and learning } \\
\text { resources with learning activities. }\end{array}$ & Tools and resources facilitate learning activities. \\
\hline
\end{tabular}

The following is the format of the suitability analysis of fourth grade students book based on Curriculum 2013 theme "The Heroes". 
Table 3.2 Format Analysis

\begin{tabular}{|l|l|l|l|}
\hline \multicolumn{2}{l}{ Subtheme } \\
Leasson learned $\quad:$ \\
\hline \multirow{2}{*}{ No } & \multicolumn{1}{|c|}{ Section to be analyzed } & \multicolumn{2}{|c|}{ The results of the analysis } \\
\cline { 3 - 4 } & & \multicolumn{1}{|c|}{ Conformity } & \\
\hline 1 & Basic competence & & \\
\hline 2 & Indicators & & \\
\hline 3 & Learning objectives & & \\
\hline 4 & Learning activities & & \\
\hline 5 & Content & & \\
\hline 6 & Learning tools and resources & & \\
\hline
\end{tabular}

\section{RESULT}

Table 3.1 Results Analysis of 4th Grade Student Book Theme "The Heroes" Subthemes "Struggle of The Heroes" Lesson 3.

\begin{tabular}{|c|c|c|}
\hline \multirow{3}{*}{ Lesson 3} & \multirow{3}{*}{ 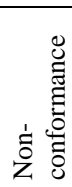 } & 1. $\quad \mathrm{KD} 4.2$ does not appear in indicators and materials. \\
\hline & & $\begin{array}{l}\text { 2. Preferably KD is concerned with ordering fractions on the subject of } \\
\text { matermatics to be added to emphasize material interrelations. }\end{array}$ \\
\hline & & $\begin{array}{l}\text { 3. IPS materials do not provide a discussion of the initial activities of } \\
\text { learning as a whole }\end{array}$ \\
\hline
\end{tabular}

\section{DISCUSSION}

Based on the results of the analysis in Table 3.1 point 1 states that KD 4.2 does not appear in the indicator and the material. KD 4.2 is a KD of Mathematics subjects about declaring fractions in decimal and percent form. While the material that appears in direct learning refers to the operation of addition and subtraction of fractions. Indicators only relate to the reduction and addition of decimal numbers while in the process also carried out the process of addition and reduction of the percent. Preferably if not used in learning activities, KD does not need to appear in the mapping.

Moreover, if we look at previous learning, the learning materials about converting ordinary fractions into new decimal fractions revolve around numerators and denominators worth tens. Students also have not learned to compare two decimal fractions. So this material is too high while the exercise is too little.

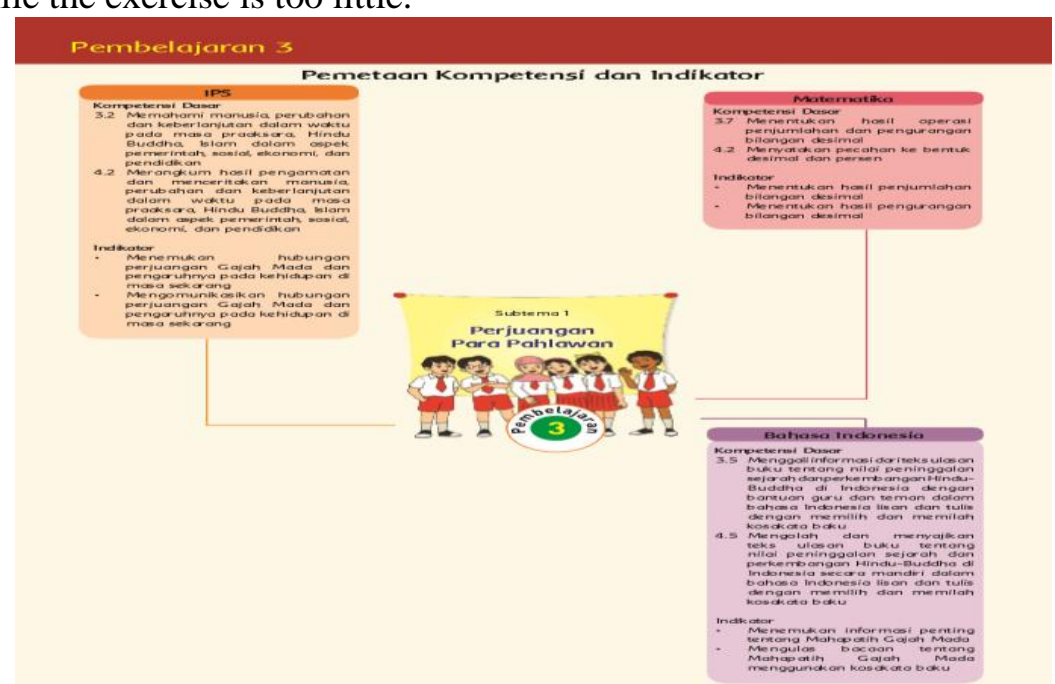

Figure 3.1 KD Mapping on Subtema 1 The Heroes Struggle in Lesson 3

4JISAE. Volume 3 Number 2 September 2017. Copyright (C) Ikacana Publisher | ISSN: 2442-4919 
If you want to adjust to the material. There is an activity of sorting the decimal fractions from the smaller to the larger and vice versa. So it is important that the relevant KDs need to be added in the mapping until they can appear in the indicators and formulated in the learning objectives.

Figure 3.2 can support the explanation that the learning activity should only contain solving the problem of addition and subtraction of decimal fractions. While in the process there is the activity of converting ordinary fractions into decimal fractions and sequencing pecaha. Afterwards the new students do the counting in the addition and subtraction operations.

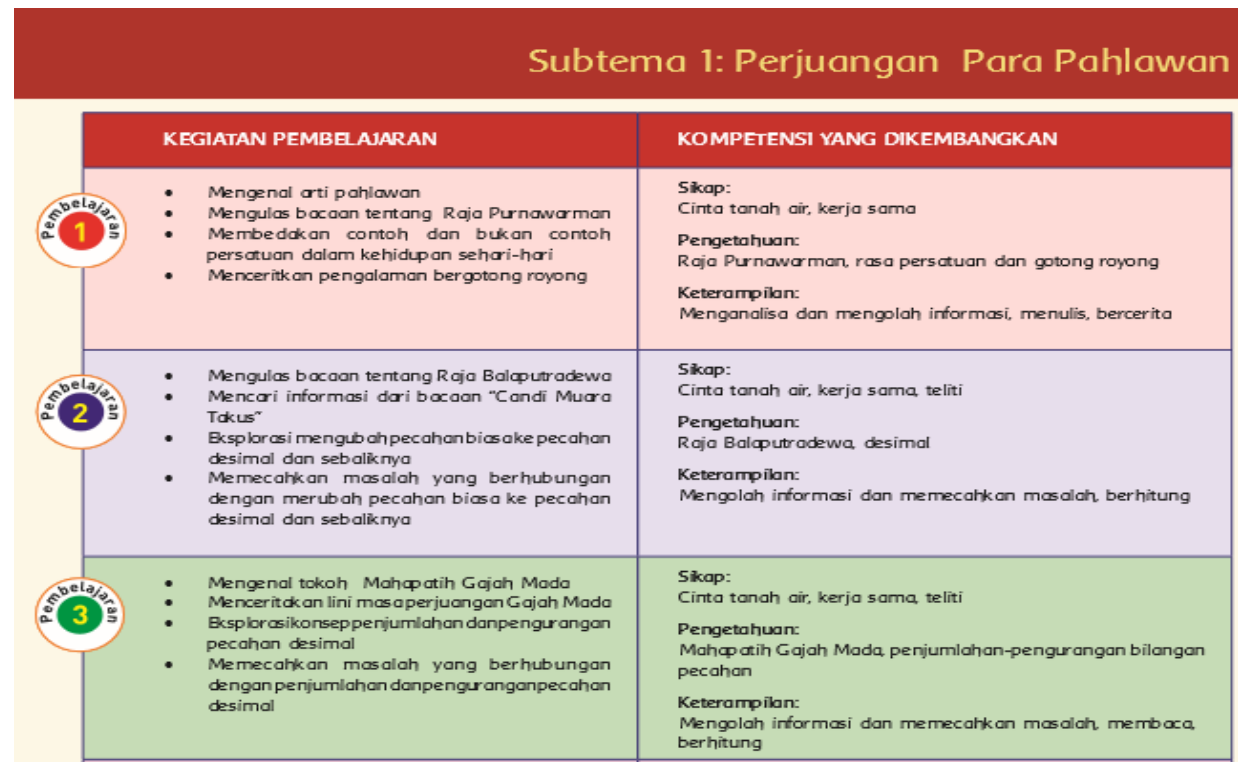

Figure 3.2 Learning Activities and Competencies Developed in Subtema 1 The Struggle of Heroes at Lesson 3

In Table 3.1 point 3 it is said that the IPS material is not discussed thoroughly. The related IPS material containing the history of Gajah Mada should be an ingredient of deep reviews in the process of reading, retelling, and discussing. But there is no linkage with previous learning using the same $\mathrm{KD}$. While the KD has been mapped, as well as in previous learning, students must understand change and sustainability in time. Then the material appears disjointed and does not become a unified whole so that students do not study the overall material that should be interconnected and support the formation of student concepts. 


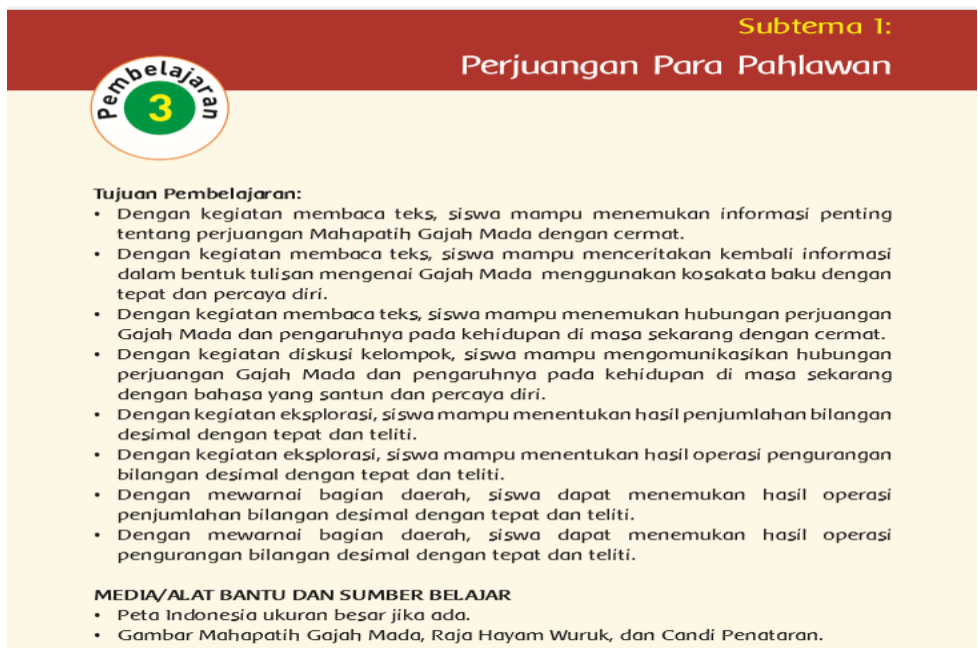

Figure 3.3 Learning Objectives in Subtema 1 The Struggle of Heroes on Lesson 3

\section{CONCLUSION}

Based on the results of this study it can be concluded that the fourth grade student's book "Heroes" theme "The Struggle of the Heroes" on the lesson 3 still found many discrepancies. These mismatches include non-emergent KDs, materials that are too narrow and incomplete material discussions.

With regard to the above conclusions the researcher suggests improving the book of fourth grade students based on the Curriculum 2013 on the theme of "Heroes" subtheme "Struggle of the Heroes" on the lesson 3 course as described in the discussion. In addition, the researcher suggests to teachers of book users to first analyze the content and suitability of the material before using the package book. Teachers should provide tools and resources to improve the meaningfulness of learning activities.

\section{REFERENCE}

Alamsari. 2013. "Menanti Implementasi Kurikulum 2013”. MGMP Bahasa Indonesia. Rabu, 18 Desember 2013. www.OganIlir.com, diakses pada tanggal 29 November 2014.

Alawiyah, Faridah. 2014. Kesiapan Guru dalam Implementasi Kurikulum 2013. Pusat Pengkajian, Pengelohan Data dan Informasi (P3DI), hal. 9.

BSNP. 2006. Panduan Penyusunan Kurikulum Tingkat Satuan Pendidikan Jenjang Pendidikan Dasar dan Menengah. Jakarta: BSNP.

BSNP. 2014. Pemaparan Wakil Menteri Pendidikan Nasional di Jakarta, 14 Januari 2014.

Desta, Mahesa Pranata. 2013. Pengaruh Sumber Belajar Terhadap Prestasi Belajar Siswa pada Mata Pelajaran Akuntansi Universitas Pendidikan Indonesia. www.perpustakaan.upi.edu, diakses pada tanggal 5 Januari 2015.

E-journal Bina Darma. Analisi Buku Teks. www.eprints.binadarma.ac.id.

Harta, Idris. 2013. Kesalahan Buku Matematika SMP Kurikulum 2013. 5 Oktober 2013. www.kompasianaedu.com. 
Ibrahim \& Syaodih. 2010. Perencanaan Pengajaran. Jakarta: Rineka Cipta.

Imam, Taufik. 2011. Perencanaan Pembelajaran. bandung: PT Remaja Rosdakarya.

Inlow, Gail M. 1966. The Emergent in Curriculum. New York: John Willey.

Kementrian Pendidikan dan Kebudayaan. 2014. Pahlawanku. Buku Guru-Edisi Revisi. Jakarta: Kementrian Pendidikan dan Kebudayaan.

Kementrian Pendidikan dan Kebudayaan. 2014. Pahlawanku. Buku Siswa-Edisi Revisi. Jakarta: Kementrian Pendidikan dan Kebudayaan.

Kurniasih \& Sani. 2014. Panduan Membuat Bahan Ajar. Buku Teks Pelajaran sesuai dengan Kurikulum 2013. Surabaya: Kata Pena.

Linggasari, Yohannie. Tim Evaluasi Kurikulum 2013 Temukan Dua Masalah Utama. 22 Januari 2015. www.CNNIndonesia.com.

Mat Bodok, ed: Sudarwan. 2013." Masih Banyak Guru di OKI belum paham Kurikulum 2013. Senin, 29 September 2014. www.Sripoku.com, diakses pada tanggal 29 November 2014.

Peraturan Menteri Pendidikan dan Kebudayaan Nasional No. 56 Tahun 2013 tentang Standar Proses Pendidikan Dasar dan Menengah.

Peraturan Menteri Pendidikan dan Kebudayaan Nasional No. 67 Tahun 2013 tentang Kerangka Dasar dan Struktur Kurikulum Sekolah Dasar/ Madrasah Ibtidaiyah.

Peraturan Menteri Pendidikan dan Kebudayaan Nasional No. 11 Tahun 2005 tentang Buku Teks Pelajaran.

Prastica, Herna Selvia. Implementasi Kurikulum 2013 Menyelamatkan Kebijakan Vs Menyelamatkan Anak Didik. 22 Oktober 2014. www.kompasianaedu.com, diakses tanggal 29 Oktober 2014.

Prastowo, Andi. 2014. Pengembangan Bahan Ajar Tematik. Tinjauan Teoretis dan Praktik. Jakarta: Kencana.

Ramly, Ishak. 2004. Inilah Kurikulum Sekolah. Malaysia: PTS Media Group.

Sudjana \& Rivai. 2003. Teknologi Pengajaran. Bandung: CV Sinar Baru.

Sugiyono. 2012. Metode Penelitian Kuantitatif, Kualitatif, dan R\&D. Bandung: Alfabeta.

Sukmadinata, Nana Syaodih. 2005. Pengembangan Kurikulum, Teori, dan Praktek. Bandung: PT Remaja Rosdakarya.

Syaodih, Nana. 2010. Metode Penelitian Pendidikan. Bandung: PT Remaja Rosdakarya.

Tim Pengembang Ilmu Pendidikan FIP-UPI. 2009. Ilmu dan Aplikasi Pendidikan. Bagian I: Ilmu Pendidikan Teoretis. Bandung: PT Imtima.

Undang-Undang No. 20 Tahun 2003 tentang Sistem Pendidikan Nasional.

Warsita, Bambang. 2008. Teknologi Pembelajaran, Landasan dan Aplikasinya. Jakarta: Rineka Cipta.

Zubaidah, Nenen. 2014. Kurikulum 2013 Terlalu Dipaksakan. 20 November 2014. www.SINDOnews.com, diakses tanggal 29 November 2014. 